JGRADASI TEKnIK SIPIL 


\section{JURNAL GRADASI TEKNIK SIPIL POLITEKNIK NEGERI BANJARMASIN}

Jurnal Gradasi Teknik Sipil diterbitkan oleh Pusat Penelitian dan Pengabdian Kepada Masyarakat Politeknik Negeri Banjarmasin. Ruang lingkup makalah meliputi Bidang Teknik dan Manajemen dengan konsentrasi Bidang Transportasi, Geoteknik, Struktur, Keairan dan Manajemen Konstruksi. Isi makalah dapat berupa penyajian isu aktual di bidang Teknik Sipil, review terhadap perkembangan penelitian, pemaparan hasil penelitian, dan pengembangan metode, aplikasi, dan prosedur di bidang Teknik Sipil. Makalah ditulis mengikuti panduan penulisan.

\section{Penanggung Jawab}

Nurmahaludin, ST, MT.

\section{Dewan Redaksi}

Ketua :

Anggota : Riska Hawinuti, ST, MT.

Nurfitriah, S.Pd, MA.

Ir. Rusliansyah, M.Sc.

\section{Reviewer}

Dr. Ir. Yanuar Jarwadi Purwanto, MS. (Institut Pertanian Bogor)

Dr. Ir. Achmad Rusdiansyah, MT. (Universitas Lambung Mangkurat)

Dr. Ir. M. Azhar, M. Sc. (Institut Sains dan Teknologi Nasional)

Dr. Ir. Endang Widjajanti, MT. (Institut Sains dan Teknologi Nasional)

Joni Irawan, ST, MT. (Politeknik Negeri Banjarmasin)

Yusti Yudiawati, ST, MT. (Politeknik Negeri Banjarmasin)

\section{Editing dan Tata Bahasa}

Nurfitriah, S.Pd., MA.

\section{Desain dan Tata Letak}

Abdul Hafizh Ihsani

\section{Alamat Redaksi}

Jurusan Gradasi Teknik Sipil Politeknik Negeri Banjarmasin, Jl. Brigjen H. Hasan Basri 70123 Banjarmasin Telp/Fax 0511-3307757; Email: gradasi.tekniksipil@poliban.ac.id 


\section{JURNAL GRADASI TEKNIK SIPIL}

\section{DAFTAR ISI}

Perencanaan Campuran Lapis Aspal Beton Permukaan Dengan Asbuton Butir Sebagai Filler ...( 1 - 9 )

Surat, Rifanie Gazalie, Pazilatul Mumamiroh

Pengaruh Keberadaan Pasar Sungai Lulut Terhadap Kinerja Jalan Martapura Lama KM. 05 ...( 10 - 19)

\section{Riska Hawinuti}

Analisis Perbandingan Biaya Penggunaan Perancah Kayu Galam Dan Perancah Besi (Scaffolding) ...( $20-32)$ Aunur Rafik, Rinova Firman Cahyani

Tinjauan Debit Andalan untuk Irigasi di Kecamatan Sungai Tabuk Kabupaten Banjar ...( $33-43)$

Fakhrurrazi, Herliyani Farial Agoes, Desi Anggeriyani

Ekosemen Sebagai Media Perekat Pengganti Semen Untuk Beton ...( 44 - 51 ) Marhadi Sastra, Juli Ardita Pribadi R

Pengaruh Posisi, Jumlah Layer Dan Mutu Kayu Terhadap Balok Laminasi Kayu Mahang Dan Kayu Meranti ...( 52 - 60 )

\section{Indriyani Puluhulawa}

Visualisasi Dan Identifikasi Pola Retak Dinding Bata Akibat Penurunan Pondasi Struktur Bangunan Di Kota Banjarmasin ...( 61 - 68 )

\section{Darmansyah Tjitradi, Eliatun}

Pengembangan Perumahan Dengan Desain Konstruksi Dilahan Basah Pada Wilayah Kota Banjarmasin Menggunakan Riset Operasi ...( 69 - 75 )

\section{Eliatun, Darmansyah Tjitradi}




\title{
Visualisasi Dan Identifikasi Pola Retak Dinding Bata Akibat Penurunan Pondasi Struktur Bangunan Di Kota Banjarmasin
}

\author{
Darmansyah Tjitradi ${ }^{1}$, Eliatun $^{2}$ \\ ${ }^{1,2}$ Dosen Jurusan Teknik Sipil Universitas Lambung Mangkurat \\ e-mail: *Itjitradi_syah@yahoo.com (corresponding author)
}

\begin{abstract}
Abstrak
Kota Banjarmasin memiliki daya dukung tanah yang sangat rendah, sehingga banyak sekali bangunan yang mengalami penurunan pondasi. Hal tersebut menyebabkan banyak sekali elemen bangunan yang mengalami retakretak dan juga menyebabkan bangunan menjadi miring. Penurunan pondasi ini akan dimodelkan dengan software ANSYS dengan mengambil lima model struktur bangunan dengan dinding bata yang akan dibebani dengan berat sendiri struktur. Melalui permodelan ini dapat divisualisasikan dan diidentifikasi pola retak dan tegangan yang terjadi pada dinding batu bata dan elemen struktur.

Dari penelitian ini diketahui bahwa kolom yang mengalami penurunan pondasi akan mengalami keretakan sepanjang kolom, pola retak pada dinding bata berupa retak diagonal pada setiap pojok bawah kolom dan retak vertikal pada tepi kolom tengah jika tidak terjadi penurunan pondasi. Pola retak pada dinding bata membentuk huruf $V$ jika hanya satu kolom tepi atau dua kolom tepi yang mengalami penurunan pondasi, dan pola retak pada dinding bata membentuk huruf $V$ terbalik jika hanya kolom tengah atau dua kolom bersebelahan yang mengalami penurunan pondasi. Penurunan pondasi pada kolom tengah yang paling banyak menyebabkan kerusakan komponen struktur.
\end{abstract}

Kata kunci-retak, dinding bata, penurunan pondasi, ANSYS

\begin{abstract}
The City of Banjarmasin has very low soil bearing capacity leading to a significant number of buildings experiencing foundation settlement. This causes many elements of the buildings to develop cracks and to lean. The foundation settlement is modelled using ANSYS by taking five building structure models with brick walls loaded with their selves weight. Through this modelling the crack pattern and the stress distribution on both walls and the structural elements can be visualised and identified.

The results show that the following columns experiencing foundation settlement develop longitudinal cracks, crack patterns on brick walls are diagonal at every bottom corner of the columns and vertical at the edge of the inner columns if there is no foundation settlement. Crack patterns on brick walls take form of a letter V if only one or two outer column experience foundation settlement, and crack patterns on brick walls also take form of an inverted letter $V$ if only the inner columns or two adjacent columns experience foundation settlement. Foundation settlement experienced by inner columns of a brick wall is a major cause of damage to structural components.
\end{abstract}

Keywords — crack, brick wall, foundation settlement, ANSYS

\section{PENDAHULUAN}

Secara keseluruhan tanah kota Banjarmasin merupakan daerah rawa yang tanahnya merupakan jenis tanah gambut dengan daya dukung tanah yang sangat lunak sekali. Lapisan tanah keras letaknya jauh sekali yaitu berkisar antara $25 \mathrm{~m}$ sampai dengan $50 \mathrm{~m}$, sehingga untuk membangun suatu bangunan digunakan pondasi tiang dengan hanya mengandalkan lekatan (friction) dari tiang. Pondasi tiang yang digunakan umumnya adalah kayu Galam dengan diameter berkisar antara 8 s.d. $15 \mathrm{~cm}$ yang berasal dari pohon Galam yang tumbuh di daerah rawa. 
Di kota Banjarmasin banyak sekali terdapat bangunan miring dan elemen struktur serta dinding batu bata yang mengalami keretakan sebagai akibat dari daya dukung tanahnya yang lunak sekali dan pondasi bangunannya yang hanya mengandalkan lekatan saja. Keretakan awal pada dinding bata merupakan indikator awal akan terjadinya penurunan kekuatan struktur terhadap elemenelemen struktur seperti balok dan kolom, dan terus berlanjut sampai terjadinya keruntuhan bangunan. Oleh karena itu perlu dilakukan penelitian yang menyelidiki hal-hal yang terkait dengan keretakan ini. Adapun tujuan dari penelitian ini adalah untuk mengetahui bagaimana pola retak dan tegangan yang terjadi pada dinding batu bata, balok, dan kolom struktur bangunan beton bertulang yang dimodelkan mengalami penurunan pondasi/ tumpuan dengan Software ANSYS.

A. Permodelan Struktur dengan menggunakan ANSYS

1) Model Beton Bertulang (Reinforced Concrete)

Untuk memodelkan material beton bertulang digunakan model 8 elemen Solid (SOLID65) dengan tiga derajat kebebasan pada setiap titiknya dan terjadi translasi pada arah $\mathrm{x}, \mathrm{y}$, and $\mathrm{z}$ (lihat Gambar 1). Elemen ini juga mempunyai kemampuan untuk berdeformasi plastis, retak dalam arah x, y, dan z. (L. Dahmani, et.al, 2010).

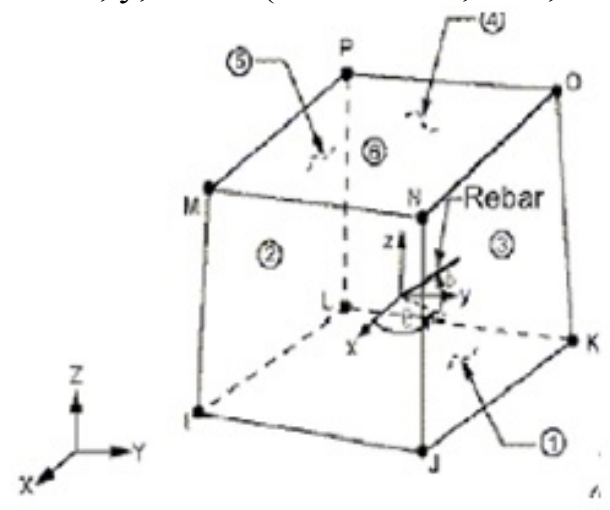

Gambar 1, Model 3D Elemen Beton SOLID65

Model kurva tegangan-regangan beton yang digunakan adalah model tegangan-regangan beton yang tidak terkekang menurut Kent-Park (1971) (Park, R., dan T. Paulay, 1975), yaitu: a) Daerah AB: $\varepsilon \mathrm{c} \leqslant 0,002$

b) Daerah BC: $0,002 \leqslant \varepsilon \mathrm{c} \leqslant \varepsilon 50 \mathrm{u}$

Dimana:

$$
\begin{gathered}
z=\frac{0,50}{\frac{3+0,002 \cdot f_{c}^{\prime}}{f_{c}^{\prime}-1000}-0,002} \\
\varepsilon_{50 u}=\frac{3+0,002 \cdot f_{c}^{\prime}}{f_{c}^{\prime}-1.000}
\end{gathered}
$$

Data sifat penampang yang akan digunakan dalam permodelan ANSYS dapat dilihat pada Tabel I.

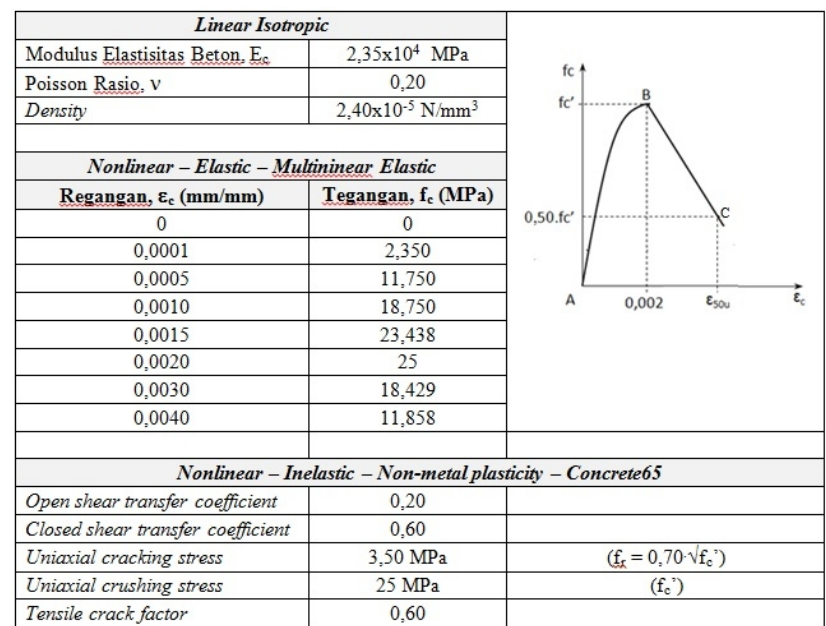

2) Model Tulangan Baja (Steel Reinforcement) Dalam memodelkan tulangan baja biasanya digunakan 2 model, yaitu:

Model 1: tulangan baja diidealisasikan sebagai elemen batang aksial (spar elements) dengan sifatnya seperti tulangan aslinya (Gambar 2a). Elemen ini dapat langsung dihasilkan dari titik-titik dalam model dan mudah digunakan dalam memodelkan tulangan baja suatu beton bertulang (digunakan dalam makalah ini). (I. Syaifullah, et.al, 2011) 
Model 2: tulangan baja diidealisasikan sebagai tulangan yang terdistribusi merata dalam elemen beton (smeared concrete element). Dalam hal ini, beton dan tulangan terdistribusi ke dalam elemen dengan batas-batas geometrik yang sama dan pengaruh tulangan merata ke dalam elemen yang berhubungan (Gambar 2b).

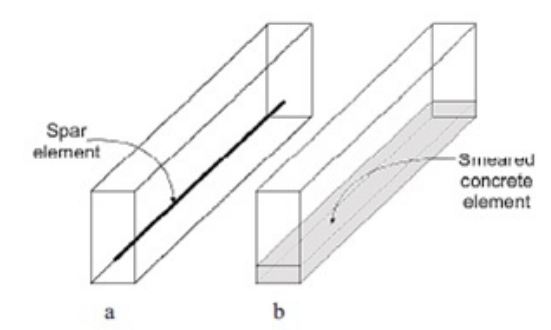

Gambar 2. Model Tulangan Baja a) model Spar Element dan b) Smeared Concrete Element

Model hubungan tegangan-regangan baja yang digunakan adalah model Bilinear Isotropic Hardening, dengan data material dapat dilihat pada Tabel II.

TABEL II. Data Material Tulangan Baja Link 8

\begin{tabular}{|l|c|}
\hline \multicolumn{2}{|c|}{ Linear Isotropic } \\
\hline Modulus Elastisitas Baja, $\mathrm{E}_{\mathrm{s}}$ & $2,00 \times 10^{5} \mathrm{MPa}$ \\
\hline Poisson Rasio, $v$ & 0,30 \\
\hline Density & $7,85 \times 10^{-5} \mathrm{~N} / \mathrm{mm}^{3}$ \\
\hline \multicolumn{2}{|c|}{$\begin{array}{c}\text { Nonlinear - Inelastic - Rate Independent - } \\
\text { Isotropic Hardening plasticity - Mises Plasticity - } \\
\text { Bilinear Isotropic Hardening }\end{array}$} \\
\hline Tegangan leleh Baja, $\mathrm{f}_{\mathrm{y}}$ & $400 \mathrm{MPa}$ \\
\hline Modulus Tangen Baja, $\mathrm{E}_{\mathrm{s}}{ }^{\prime}$ & $2,00 \times 10^{3} \mathrm{MPa}$ \\
\hline
\end{tabular}

3) Model Batu Bata (Brick)

Untuk memodelkan material batu bata (200mmx100mmx50mm) digunakan model 8 elemen Solid (SOLID65) dengan tiga derajat kebebasan pada setiap titiknya dan terjadi translasi pada arah x, y, and z (Gambar 1). Elemen ini juga mempunyai kemampuan untuk berdeformasi plastis, retak dalam arah x, y, dan z. (Uday Vyas, 2009). Data sifat penampang yang akan digunakan dalam permodelan ANSYS dapat dilihat pada Tabel III.
TABEL III. Data Material Batu Bata SOLID

\begin{tabular}{|c|c|c|}
\hline \multicolumn{2}{|c|}{ Linear Isotropic } & \\
\hline Modulus Elastisitas Beton, $\mathrm{E}_{\mathrm{c}}$ & $1.45 \times 10^{4} \mathrm{MPa}$ & \\
\hline Poisson Rasio, $v$ & 0.18 & \\
\hline Density & $1.675 \times 10^{-5} \mathrm{~N} / \mathrm{mm}^{3}$ & 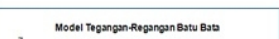 \\
\hline & & $\sim$ \\
\hline \multicolumn{2}{|c|}{ Nonlinear-Elastic-Multilinear Elastic } & \\
\hline Regangan, $\varepsilon_{\mathrm{c}}(\mathrm{mm} / \mathrm{mm})$ & Tegangan, $\mathrm{f}_{\mathrm{c}}(\mathrm{MPa})$ & \\
\hline 0 & 0.000 & $\vec{x}_{1}^{2}$ \\
\hline 0.00013 & 1.885 & 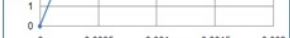 \\
\hline 0.00015 & 2.175 & $\begin{array}{l}0.0005 \\
\text { Regangan Tekan Bata }\end{array}$ \\
\hline 0.00019 & 2.500 & \\
\hline 0.00027 & 3.210 & \\
\hline 0.00038 & 4.000 & \\
\hline 0.00049 & 4.530 & \\
\hline 0.00058 & 4.900 & \\
\hline 0.00081 & 5.700 & \\
\hline 0.00143 & 6.300 & \\
\hline \multicolumn{3}{|c|}{ Nonlinear - Inelastic - Non-metal plasticity - Concrete 65} \\
\hline Open shear transfer coefficient & 0.2 & \\
\hline Closed shear transfer coefficient & 0.5 & \\
\hline Uniaxial cracking stress & $0.71 \mathrm{MPa}$ & \\
\hline Uniaxial crushing stress & $5 \mathrm{MPa}$ & \\
\hline
\end{tabular}

\section{METODE PENELITIAN}

Metode penelitian yang digunakan adalah: (1) studi literatur dilakukan dengan mendalami materi yang relevan dengan penelitian, yang meliputi berbagai buku teks, jurnal ilmiah, peraturan dan Standar Nasional maupun Internasional; (2) membuat permodelan struktur bangunan yang menggunakan dinding bata dengan menggunakan software ANSYS dan menyertakan berat sendiri struktur (Gambar 3); (3) membuat permodelan struktur bangunan dengan dinding bata dengan variasi penurunan pondasi (Tabel IV); (4) mengkaji hasil ANSYS berupa pola retak dinding bata, beban, dan tegangan yang terjadi dan (5) membuat kesimpulan hasil dari permodelan sesuai dengan tujuan.

Dalam penelitian ini diambil kasus struktur beton bertulang yang tumpuannya mengalami penurunan akibat daya dukung tanahnya lunak seperti kasus di Banjarmasin. Model struktur beton bertulang dapat dilihat pada Gambar 3 dan Tabel IV. 

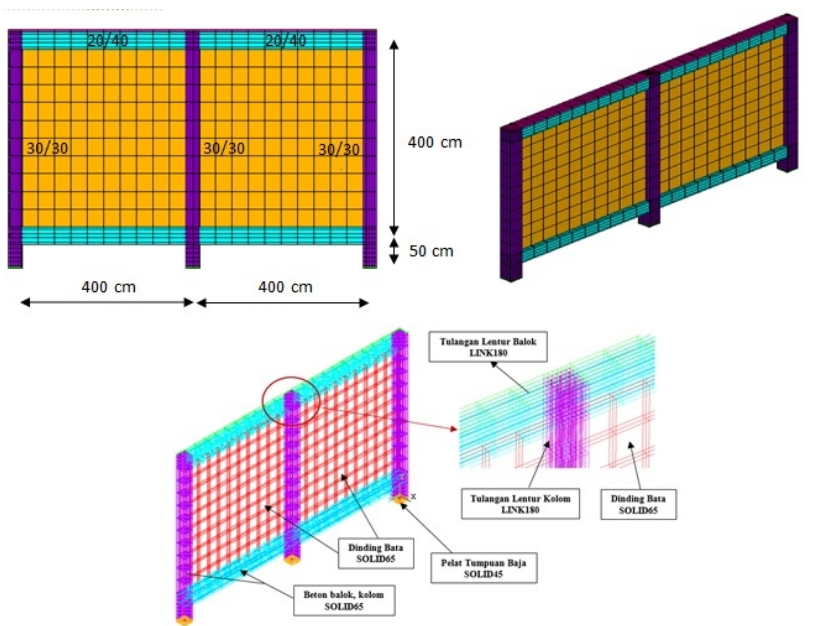

Gambar 3. Permodelan Struktur Beton Bertulang dengan dinding bata

TABEL IV. Data Model Struktur Beton Bertulang di ANSYS.

\begin{tabular}{|c|c|c|c|}
\hline Material & Elemen & Dimensi & Element Type \\
\hline \hline \multirow{2}{*}{ Beton } & Balok & 20x40x370 & SOLID 65 \\
\cline { 2 - 4 } & Kolom & $30 \times 30 \times 360$ & SOLID 65 \\
\hline Bata & Dinding Bata & $370 \times 370$ & SOLID 65 \\
\hline Baja & Tumpuan & $30 \times 30 \times 5$ & SOLID 45 \\
\hline \multirow{2}{*}{ Baja } & Tulangan Lentur Balok & 2D16 $\left(\mathrm{As}=401,92 \mathrm{~mm}^{2}\right)$ & LINK 8 \\
\cline { 2 - 4 } & Tulangan Lentur kolom & 8D16 $\left(\mathrm{As}=1607.68 \mathrm{~mm}^{2}\right)$ & LINK 8 \\
\hline
\end{tabular}

Konfigurasi model struktur beton bertulang dengan variasi penurunan tumpuan dapat dilihat pada Tabel V, nilai penurunan diambil berdasarkan Skempton dan MacDonal (1955) yang menyarankan batas-batas penurunan maksimum berkisar antara 40 s.d. $100 \mathrm{~mm}$ (Hardiyatmo, H. C, 2002).

TABEL V. Konfigurasi Model Struktur Beton Bertulang Bata.

\begin{tabular}{|c|l|c|c|c|}
\hline \multirow{2}{*}{ No. } & \multirow{2}{*}{$\begin{array}{c}\text { Kode } \\
\text { Benda Uji }\end{array}$} & \multicolumn{3}{|c|}{ Deformasi Tumpuan } \\
\cline { 3 - 5 } & & $\begin{array}{c}\text { Tumpuan } \\
\text { Kiri }\end{array}$ & $\begin{array}{c}\text { Tumpuan } \\
\text { Tengah }\end{array}$ & $\begin{array}{c}\text { Tumpuan } \\
\text { Kanan }\end{array}$ \\
\hline \hline 1 & PDB. 0.0 .0 & 0 & 0 & 0 \\
\hline 2 & PDB. 0.0 .100 & 0 & 0 & 100 \\
\hline 3 & PDB. 0.50 .100 & 0 & 50 & 100 \\
\hline 4 & PDB. 0.100 .0 & 0 & 100 & 0 \\
\hline 5 & PDB. 100.0 .100 & 100 & 0 & 100 \\
\hline
\end{tabular}

Ket: $P D B=$ Portal Dinding Bata

\section{HASIL DAN PEMBAHASAN}

Berdasarkan hasil dari analisis software ANSYS dapat diketahui pola tegangan Von Misses, retak yang terjadi pada setiap model benda uji, dan total berat bangunan sebesar $131.060 \mathrm{~N}$.

\section{a) Model PDB.0.0.0}

Pada model ini struktur beton bertulang tidak mengalami deformasi pada tumpuan. Dari Gambar 4 pada kondisi awal (884.655 N (675\% x total berat bangunan)) dapat dilihat bahwa dinding bata mengalami retak geser yang terjadi pada bagian pojok bawah kolom tengah, dan seluruh elemen balok, kolom belum terjadi retak. Sedangkan kondisi ultimit $(1.965 .900 \mathrm{~N}(1500 \% \mathrm{x}$ total berat bangunan)) dinding bata terjadi retak diagonal pada bagian bawah setiap pojok kolom dan retak vertikal pada tepi kolom tengah, dan elemen balok pada daerah tumpuan kolom tengah mengalami retak, serta kolom tengah pada pertemuan balok bawah mengalami retak.
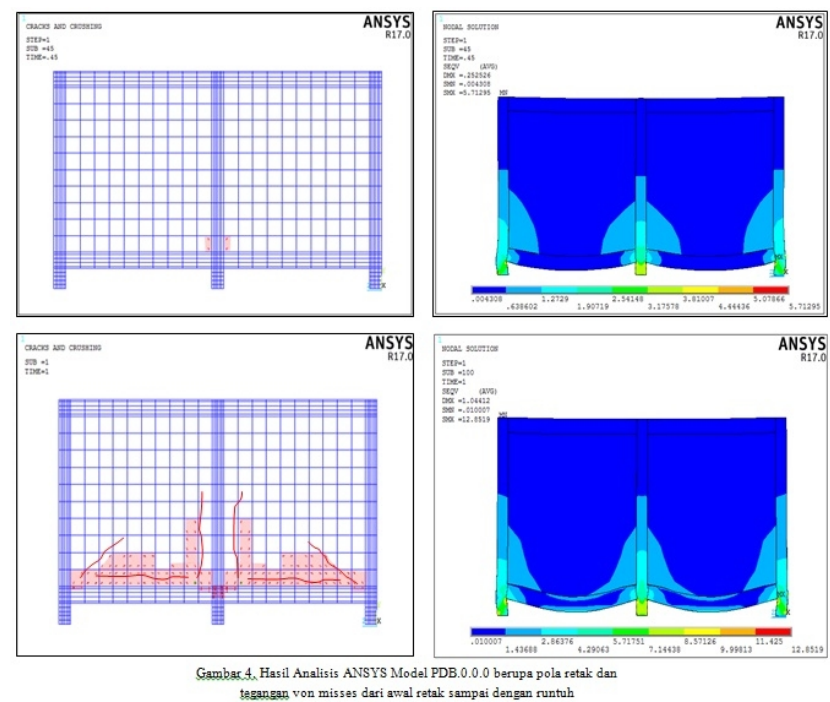

b) Model PDB.0.0.100

Pada model ini struktur beton bertulang mengalami penurunan pada tumpuan kanan sebesar $100 \mathrm{~mm}$. Dari Gambar 5 pada kondisi awal $(1.310,600 \mathrm{~N}(1,0 \% \mathrm{x}$ total berat bangunan)) dapat dilihat bahwa dinding bata mengalami retak geser yang terjadi pada bagian bawah tepi daerah kolom 
kanan, dan elemen kolom kanan bagian bawah mengalami retak dan pecah. Sedangkan kondisi ultimit (14.416,600 N (11\% x total berat bangunan)) keseluruhan dinding bata mengalami keretakan, dan kolom kiri, kolom tengah, serta kolom kanan bagian bawah mengalami retak dan pecah, dan pola retak dominan membentuk huruf V (lihat retak warna biru).

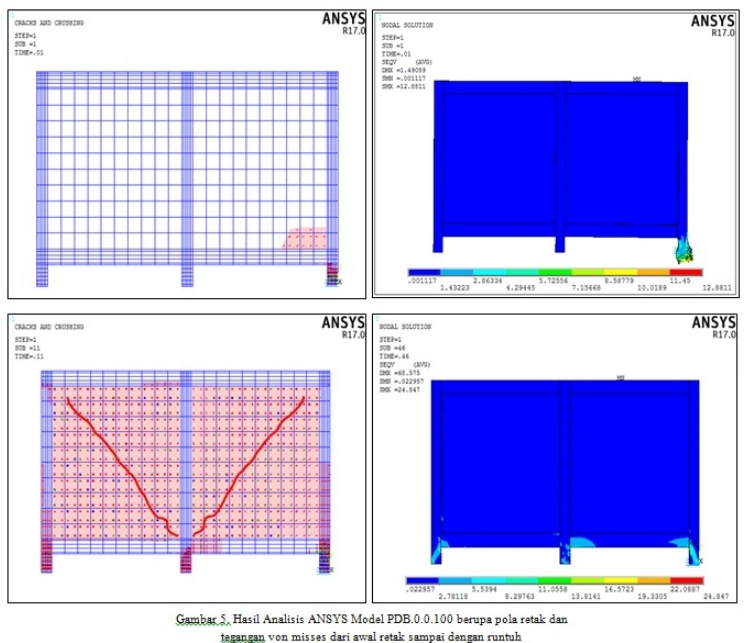

c) Model PDB.0.50.100

Pada model ini struktur beton bertulang mengalami penurunan pada tumpuan tengah sebesar $50 \mathrm{~mm}$ dan tumpuan kanan sebesar $100 \mathrm{~mm}$. Dari Gambar 6 pada kondisi awal $(78.636 \mathrm{~N}(60 \% \mathrm{x}$ total berat bangunan)) dapat dilihat bahwa dinding bata mengalami retak geser yang terjadi pada bagian bawah tepi daerah kolom tengah, dan semua bagian bawah kolom mengalami retak dan pecah. Sedangkan kondisi ultimit (116.643,400 N (89\% x total berat bangunan)) pola retak geser dinding bata terjadi pada diagonal kolom tepi ke kolom tengah dan menjalar naik pada tepi kolom tengah membentuk pola huruf $\mathrm{V}$ terbalik, dan balok bawah bagian bentang kiri dan kanan pada daerah tumpuan juga mengalami keretakan.

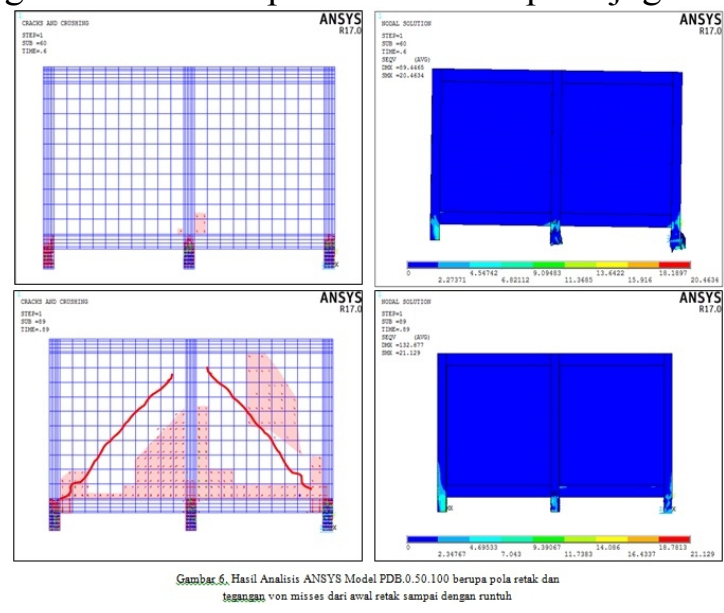

d) Model PDB.0.100.0

Pada model ini struktur beton bertulang mengalami penurunan pada tumpuan tengah sebesar $100 \mathrm{~mm}$. Dari Gambar 7 pada kondisi awal (1.310,600 N (1,0\%xtotal berat bangunan)) dapat dilihat bahwa dinding 
bata mengalami retak geser yang terjadi pada bagian bawah tepi daerah kolom tengah, dan elemen kolom tengah bagian bawah mengalami retak dan pecah. Sedangkan kondisi ultimit $(60.287,600 \mathrm{~N}$ (46\% x total berat bangunan)) pola retak geser dinding bata berbentuk huruf $\mathrm{V}$ terbalik (lihat retak warna biru) pada diagonal kolom tepi ke kolom tengah, dan kolom kiri, kolom kanan, serta kolom tengah bagian bawah mengalami retak dan pecah, dan balok bawah bagian bentang kiri dan kanan pada daerah tumpuan juga mengalami keretakan.

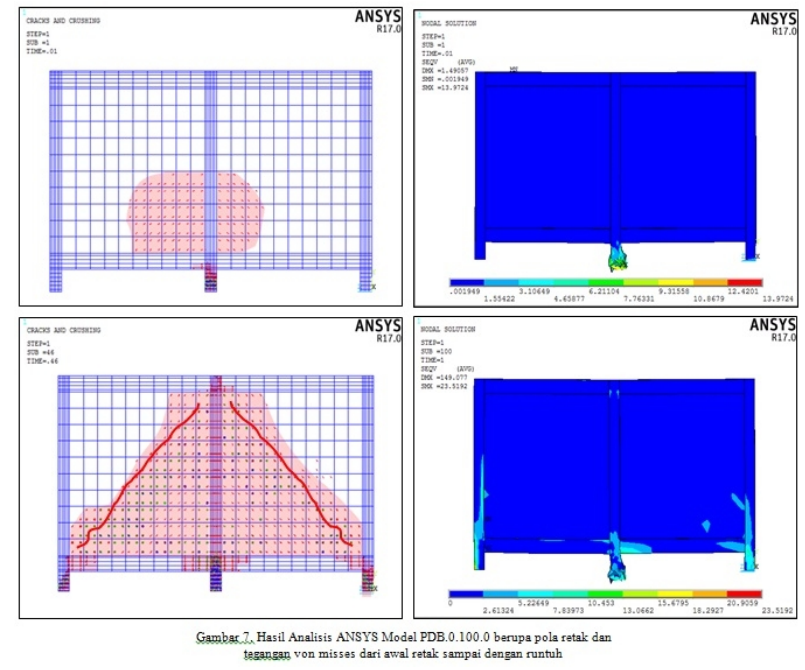

e) Model PDB.100.0.100

Pada model ini struktur beton bertulang mengalami penurunan pada tumpuan kiri sebesar $100 \mathrm{~mm}$ dan tumpuan kanan sebesar $100 \mathrm{~mm}$. Dari Gambar 8 pada kondisi awal $(1.310,600 \mathrm{~N}(1,0 \% \mathrm{x}$ total berat bangunan)) dapat dilihat bahwa dinding bata mengalami retak geser yang terjadi pada bagian tepi kolom kiri dan kolom kanan, dan elemen kolom kiri, dan kolom kanan mengalami retak dan pecah. Sedangkan kondisi ultimit (58.977 N (45\% x total berat bangunan)) keseluruhan dinding bata mengalami keretakan, elemen kolom tengah bagian bawah mengalami retak dan pecah, sepanjang elemen kolom kiri dan kolom kanan mengalami retak dan pecah, balok bawah bentang kiri dan kanan pada daerah tumpuan mengalami keretakan, dan pola retak dominan membentuk huruf V (retak warna biru).

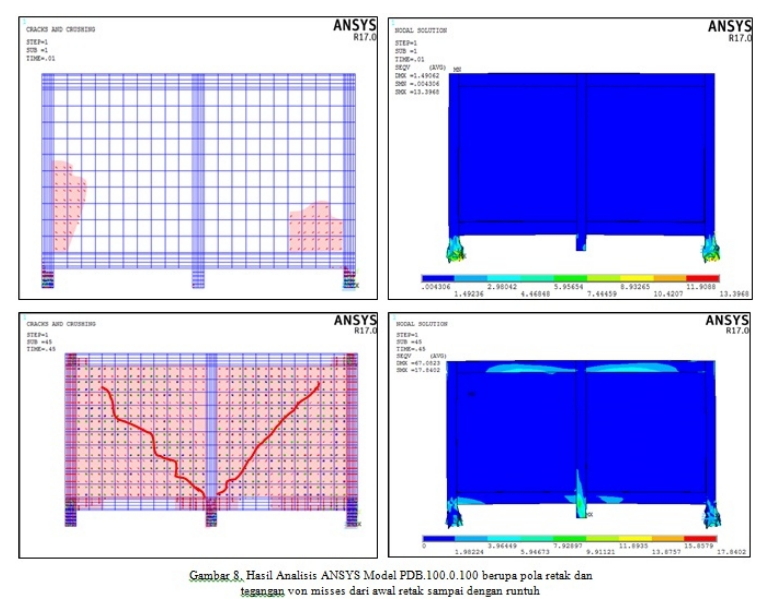


Dari Gambar 4 sd. 8 dapat diketahui bahwa pada kondisi beban awal keretakan hanya terjadi pada dinding yang berdekatan dengan kolom bagian bawah/ pondasi yang mengalami penurunan. Sedangkan pada kondisi beban ultimit dengan hasil bahwa jika tidak terjadi penurunan pondasi maka pola retak yang terjadi adalah retak diagonal pada setiap pojok bawah kolom (lihat Gambar 9), dan jika hanya satu kolom tepi atau dua kolom tepi yang mengalami penurunan pondasi maka pola retak membentuk huruf $\mathrm{V}$ (Gambar 10), namun jika hanya kolom tengah atau dua kolom bersebelahan yang mengalami penurunan maka pola retak yang terjadi membentuk huruf V terbalik (Gambar 11).

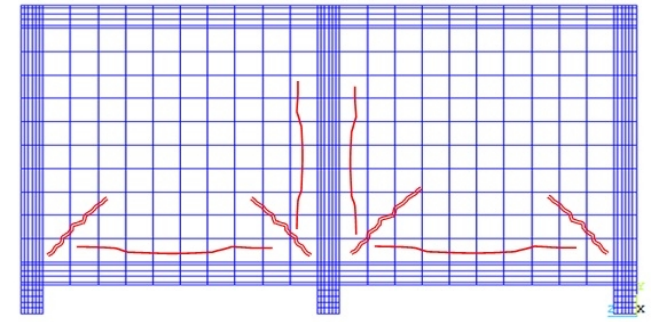

Gambar 9. Pola retak pada dinding bata jika tidak mengalami penurunan pondasi

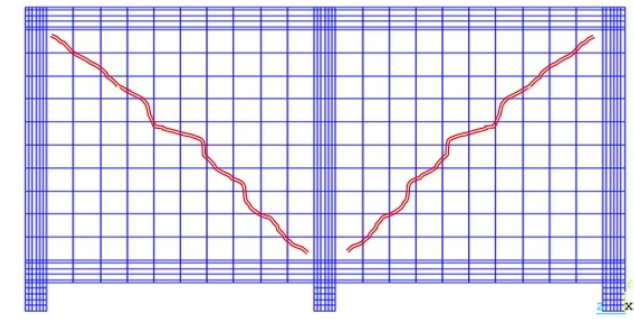

Gambar 10. Pola retak pada dinding bata jika hanya satu kolom tepi atau dua kolom tepi yang mengalami penurunan pondasi

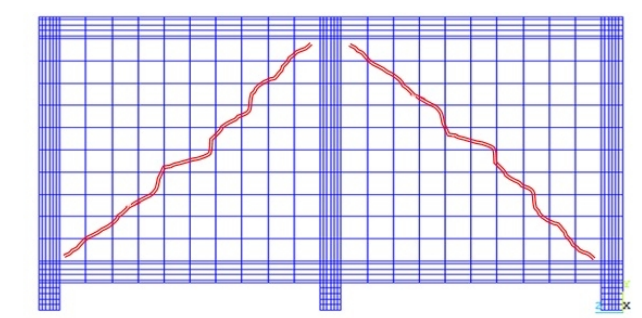

Gambar 11. Pola retak pada dinding bata jika hanya kolom tengah atau dua kolom bersebelahan yang mengalami penurunan pondasi

\section{KESIMPULAN}

Dari hasil analisis permodelan software ANSYS terhadap struktur beton bertulang dengan dinding batu bata dapat disimpulkan. Kolom yang mengalami penurunan pondasi akan mengalami keretakan sepanjang kolom. Pola retak pada dinding bata berupa retak diagonal pada setiap pojok bawah kolom dan retak vertikal pada tepi kolom tengah jika tidak terjadi penurunan pondasi. Pola retak pada dinding bata membentuk huruf $\mathrm{V}$ jika hanya satu kolom tepi atau dua kolom tepi yang mengalami penurunan pondasi. Pola retak pada dinding bata membentuk huruf $\mathrm{V}$ terbalik jika hanya kolom tengah atau dua kolom bersebelahan yang mengalami penurunan pondasi. Penurunan pondasi pada kolom tengah yang paling banyak menyebabkan kerusakan komponen struktur. Dengan menggunakan visualisasi tegangan von misses dapat diketahui besarnya tegangan setiap komponen struktur sehingga dapat diketahui lokasi komponen struktur yang berpotensi mengalami kerusakan.

\section{UCAPAN TERIMA KASIH}

Ucapan terima kasih kepada Fakultas Teknik ULM yang telah memberikan bantuan dana dalam melaksanakan penelitian ini.

\section{REFERENSI}

Ch. V. Uday Vyas, B. V. Venkatarama Reddy, 2009. Prediction of Solid Block Masonry Prism Compressive Strength Using Fe Model, Materials and Structures (2010) 43:719-735.

Hardiyatmo, H. C, 2002. Teknik Pondasi I, Penerbit PT. Beta Offset, Yogyakarta.

I. Saifullah, M. Nasir-uz-zaman, S.M.K. Uddin, M.A. Hossain and M.H. Rashid, 2011. Experimental and Analytical Investigation of Flexural Behavior of Reinforced Concrete Beam, International Journal of Engineering \& Technology IJET-IJENS Vol: 11 No: 01.

L. Dahmani, A. Khennane, and S. Kaci, 2010. Crack Identification In Reinforced Concrete Beams Using Ansys Software, Strength of 
Materials, Vol. 42, No. 2, Springer Science + Business Media, Inc.

Park, R., dan T. Paulay, 1975. Reinforced Concrete Structures, John Wiley \& Sons Inc. 